\title{
Direct effects and feedback of desert dust on the climate of the Arabian Peninsula during the wet season: a regional climate model study
}

\author{
M. Nazrul Islam • Mansour Almazroui
}

Received: 28 July 2011/ Accepted: 12 January 2012/Published online: 28 January 2012

(C) The Author(s) 2012. This article is published with open access at Springerlink.com

\begin{abstract}
We investigate the dust radiative forcing and its feedback on the Arabian Peninsula's wet season climate using the International Centre for Theoretical PhysicsRegional Climate Model (ICTP-RegCM4). We have found that the dust plumes exert a negative (positive) radiative forcing at the surface (top of the atmosphere) by reducing incoming solar radiation reaching the ground and locally heating up the atmosphere column. Consequently, the surface air temperature is cooler, hence indicating a decrease in the warm bias and an increase in the temperature gradient. This reduces the geopotential heights and enhances the low-level wind convergence, suggesting stronger upward motion. These changes increase evaporation, the difference between precipitation and evaporation in the atmosphere and rainfall over the Peninsula, indicating an intensification of the hydrologic cycle. The decrease in the precipitation dry bias and the large reduction in the temperature warm bias caused by the impact of dust over the entire Peninsula represent a significant success for the RegCM4 simulation. Therefore, the inclusion of dust in the simulation of the Arabian Peninsula's climate for the wet season contributes to an improved performance of this regional climate model over the region.
\end{abstract}

Keywords Arabian Peninsula · Dust aerosol · Regional climate model · Precipitation · Temperature

M. N. Islam ( $\square) \cdot$ M. Almazroui Center of Excellence for Climate Change Research, Department of Meteorology, King Abdulaziz University, PO Box 80234, Jeddah 21589, Saudi Arabia

e-mail: mnislam@kau.edu.sa

\section{Introduction}

The climate of the Arabian Peninsula is arid and semi-arid (Al-Mazroui 1998; Ragab and Prudhomme 2000). The world largest sand desert, the Rub Al-Khali, is located in the south-eastern parts of the Peninsula, where surface albedo is high (Atlas 1984; Edgell 2006; Bishop 2010). The higher surface albedo causes low temperatures and less precipitation in the region. Almazroui (2011a) found that the regional climate model RegCM3 successfully simulates the overall patterns of the annual precipitation in the Arabian Peninsula, when averaged over 1998-2009. However, he reported that the model overestimates precipitation compared to the Tropical Rainfall Measuring Mission (TRMM) observation data over the Peninsula for the wet season (November-April). The wet season precipitation in the northern Arabian Peninsula is important because this region is completely rainless during the dry season (June-September) (Almazroui 2011b). The wet season precipitation, which occurs primarily in the northern Peninsula, is the main source of water for human consumption and agriculture in the region (Abdullah and Al-Mazroui 1998; Al-Jerash 1985).

The air temperature is another climatic parameter that affects the socio-economy of the study region. As mention earlier, the temperature is relatively high over the Peninsula, and is highest in the Rub Al-Khali area. For understanding the diverse impacts of temperature in many application-oriented tasks related to climate change, model-simulated temperature projection is invaluable. The climate model RegCM4 simulation shows a warm bias for temperature over the Arabian Peninsula (Almazroui 2012a). To date, no previous study has thoroughly investigated the cause of such bias occurring over the Peninsula, making this an interesting area to examine and discuss. 
There have been many studies using RegCM for the simulation of climate in different regions of the world, such as in the Arabian Peninsula (Almazroui 2011a, 2012b), East Asia (Park et al. 2008), Africa (Sylla et al. 2010), Europe (Bergant et al. 2007), the Mediterranean (Krichak et al. 2010), North America (Dai et al. 1999), South Asia (Dash et al. 2006), and South America (Cuadra and da Rocha 2007). However, some studies have also reported on the impact of dust aerosol on the regional climate, mostly over East Asia (Wu et al. 2010), Southern Africa (Tummon et al. 2010) and West Africa (Zakey et al. 2006; Solmon et al. 2008; Konaré et al. 2008). They showed that dust aerosol affects the local climatic parameters, specifically precipitation and temperature, by modifying the radiative forcings. It is also known that atmospheric aerosols play an important role in the global climate system, and influence the global radiation budget directly through scattering and absorption (Stier et al. 2005; Ångström 1962; McCormic and Ludwig 1967). Hence, aerosol ultimately changes the climate at the regional scale.

To date, there has been no particular work based on how dust aerosol affects the climate of the Arabian Peninsula. In fact, the Peninsula, in addition of being the location of significant dust sources, is itself located in between two of the world's largest dust sources: Africa and Asia (Tummon et al. 2010; Stier et al. 2005; Tegen et al. 2002). The Peninsula is bounded by the Red Sea to the west, the Arabian Sea to the south and the Arabian Gulf to the east (Fig. 1). The topography is almost entirely flat desert, except for some mountains in the far southwest and, to a lesser extent, in the northwest. The climate of the Peninsula is also influenced by phenomena in the Mediterranean (winter characteristics) and the Indian Ocean (summer characteristics) (Chakraborty et al. 2006). As a result, it could be interesting to study the effects of desert dust on the climate of the Arabian Peninsula.

In order to quantify the dust direct radiative forcing effects in the Arabian Peninsula's climate, the International Centre for Theoretical Physics-Regional Climate Model (ICTP-RegCM4) is used in this study. The analysis is focused mainly on the impact of desert dust on the surface temperature and precipitation over the Arabian Peninsula during the wet season. In particular, we will investigate how the dust radiative forcing impacts on the temperature and the rainfall biases by modifying the atmospheric circulation.

The model and experimental set-up are described in Sect. 2. Section 3 presents the results of the radiative
Fig. 1 Analysis domain showing the topography (in $\mathrm{m}$ ) in and around the Arabian Peninsula. Two homogeneous sub-regions NAP and SAP are used later for statistical calculations

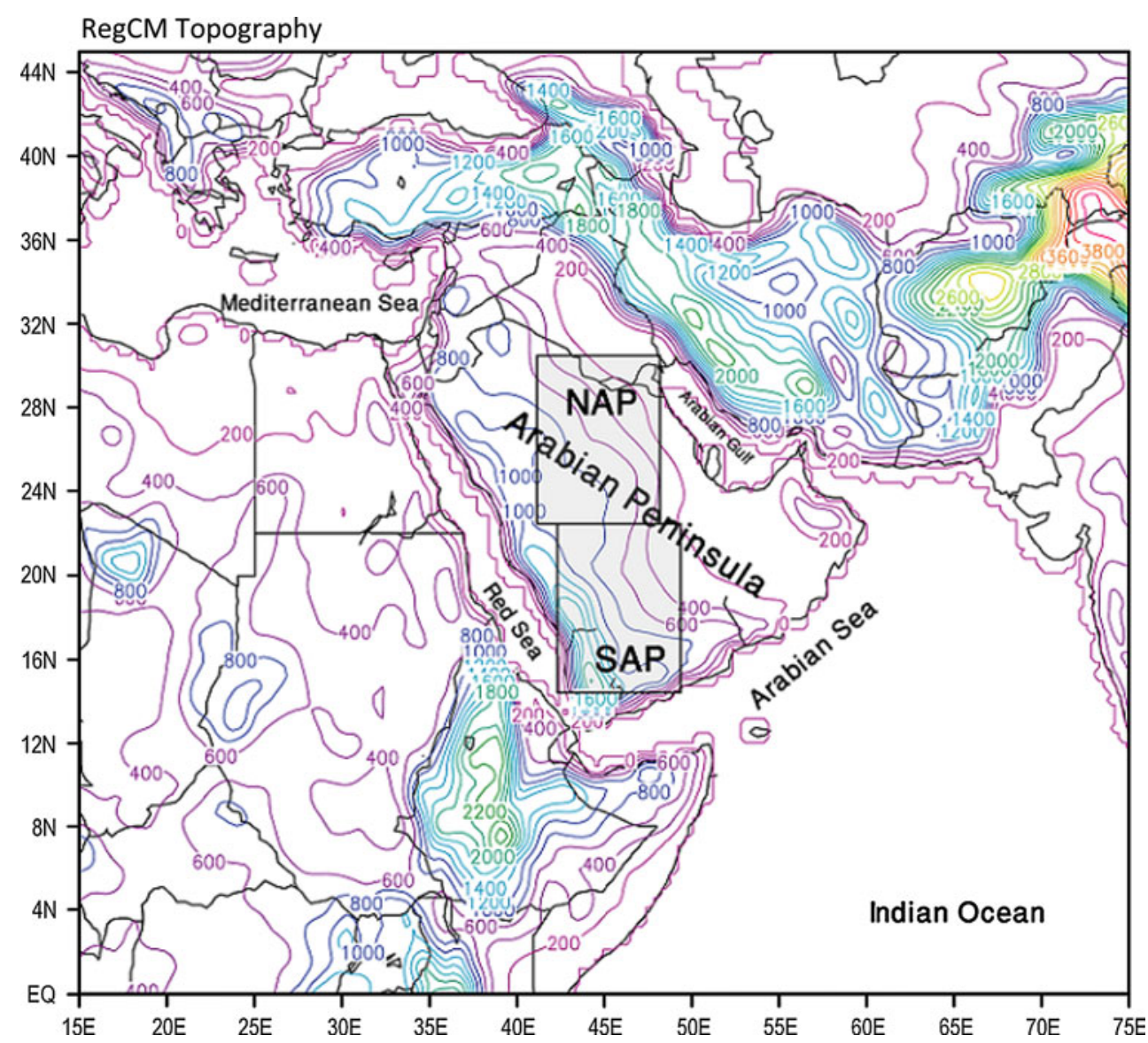


forcing, temperature and precipitation, whilst conclusions are presented in Sect. 4.

\section{Model description and experimental set-up}

The study is performed using the current version of the ICTP community model RegCM4 (see for details, Giorgi et al. 2012), which is an evolution of its previous version RegCM3 described by Pal et al. (2007). Keeping the same basic model dynamics as in RegCM3, RegCM4 is a hydrostatic, compressible, sigma-p vertical coordinate model run on an Arakawa B-grid, in which wind and thermodynamical variables are horizontally staggered. The radiative transfer scheme of the global model CCM3 (Kiehl et al. 1996) is adopted in RegCM4. The scattering and absorption of solar radiation by aerosols are included in the model, based on the aerosol optical parameters (Zakey et al. 2006; Solmon et al. 2006, 2008). In RegCM4, the contribution of the infrared spectrum is implemented according to Solmon et al. (2008), and the modified planetary boundary layer (PBL) processes follow the work of Holtslag et al. (1990).

In these simulations, convective rainfall is treated by the Grell scheme (1993) in the implementation of Giorgi et al. (1993) with the Fritsch and Chappell closure assumption (1980), which was tested for this region by Almazroui (2011a). The resolvable scale precipitation scheme is based on the SUBEX parameterization of Pal et al. (2000), and the land surface processes are described by the BiosphereAtmosphere Transfer Scheme (BATS) of Dickinson et al. (1993) and Gao et al. (2006).

The model domain has been selected as $15^{\circ}-75^{\circ} \mathrm{E}$ and $0^{\circ}-45^{\circ} \mathrm{N}$, covering the entire Arabian Peninsula and its surroundings (Fig. 1). The horizontal grid resolution of $50 \mathrm{~km}$ is used, and the model includes 18 vertical layers. We employ as initial and lateral boundary conditions, the European Centre for Medium-Range Weather Forecasts (ECMWF) reanalysis ERA interim (ERA-int; Simmons et al. 2007) dataset. The NOAA Optimum Interpolation Sea Surface Temperature-OISS V2 (Reynolds et al. 2002) is used as SST forcing. The land-use and topography data are from the United States Geological Survey (USGS) and from the Global Land Cover Characterization (GLCC) datasets (Loveland et al. 2000).

In the first run, a testing set-up of RegCM4 without the dust module (control run) is performed from 1 January 1997 through 31 December 2009; the first year of the model run is discarded as the spin-up period (not used in the analysis). In the second run, RegCM4 is driven with same specifications and for the same period as the first run but including the dust module (Zakey et al. 2006; Solmon et al. 2008). The analysis is carried out by comparing seasonal (November-April) RegCM4 simulated temperature with the Climatic Research Unit observation (CRU; Mitchell and Jones 2005) and precipitation with TRMM (Kummerow et al. 2000) data. The CRU $\left(0.5^{\circ} \times 0.5^{\circ}\right.$ resolution) is only rain-gauge-based monthly rainfall data, whereas TRMM $\left(0.25^{\circ} \times 0.25^{\circ}\right.$ resolution $)$ is the $3 \mathrm{~B} 42$ version 6 , which is a merged product of radar, satellite and gauge-based information. The analysis of model performance includes regional average of mean bias and Root Mean Square Difference (RMSD), and the impact of dust is signified by differentiating the two simulations.

\section{Results}

\subsection{Dust sources and properties}

Before evaluating the impact of desert dust on the Arabian Peninsula's climate, it is worth detailing the main dust sources in the region. Figure $2 \mathrm{a}, \mathrm{b}$ display the dust concentrations at the first model level $(1,000 \mathrm{hPa})$ and the Aerosol Optical Depth (AOD, column burden in current work), respectively. As the dust particles are generated by the strong near-surface winds, the maxima shown in Fig. 2a are thus very close to the dust sources. Therefore, in the Arabian Peninsula, the main location of the dust sources lies mostly in the central regions. In addition, the current analysis domain is very close to the significant dust sources of northern Africa, and therefore plumes can be transported to the Peninsula (depending on wind direction), which may strongly impact the climate of the study region.

The AOD maxima are shown in the southern part of the Peninsula and the Arabian Sea, suggesting that, although the dust sources are mainly localized, the plumes are widely spread across the neighboring regions; these areas lie in the main exit pathways of dust transport from continental Africa, which may strongly impact the simulated surface temperature via the radiative forcing.

\subsection{Radiative forcing and surface air temperature}

Figure 3a, b show the clear-sky total (shortwave and longwave) radiative forcing at the top of the atmosphere (TOA) and at the surface, respectively. The clear-sky TOA radiative forcing indicates whether there is a cooling or warming of the surface-troposphere system. At the top of the atmosphere, the total radiative forcing due to the dust, dominated by the shortwave contribution (not shown), is positive almost everywhere in the Arabian Peninsula, suggesting an increase in the radiative energy budget of the surface-atmosphere column, which ultimately leads to a net warming of the system. The highest magnitudes are found 

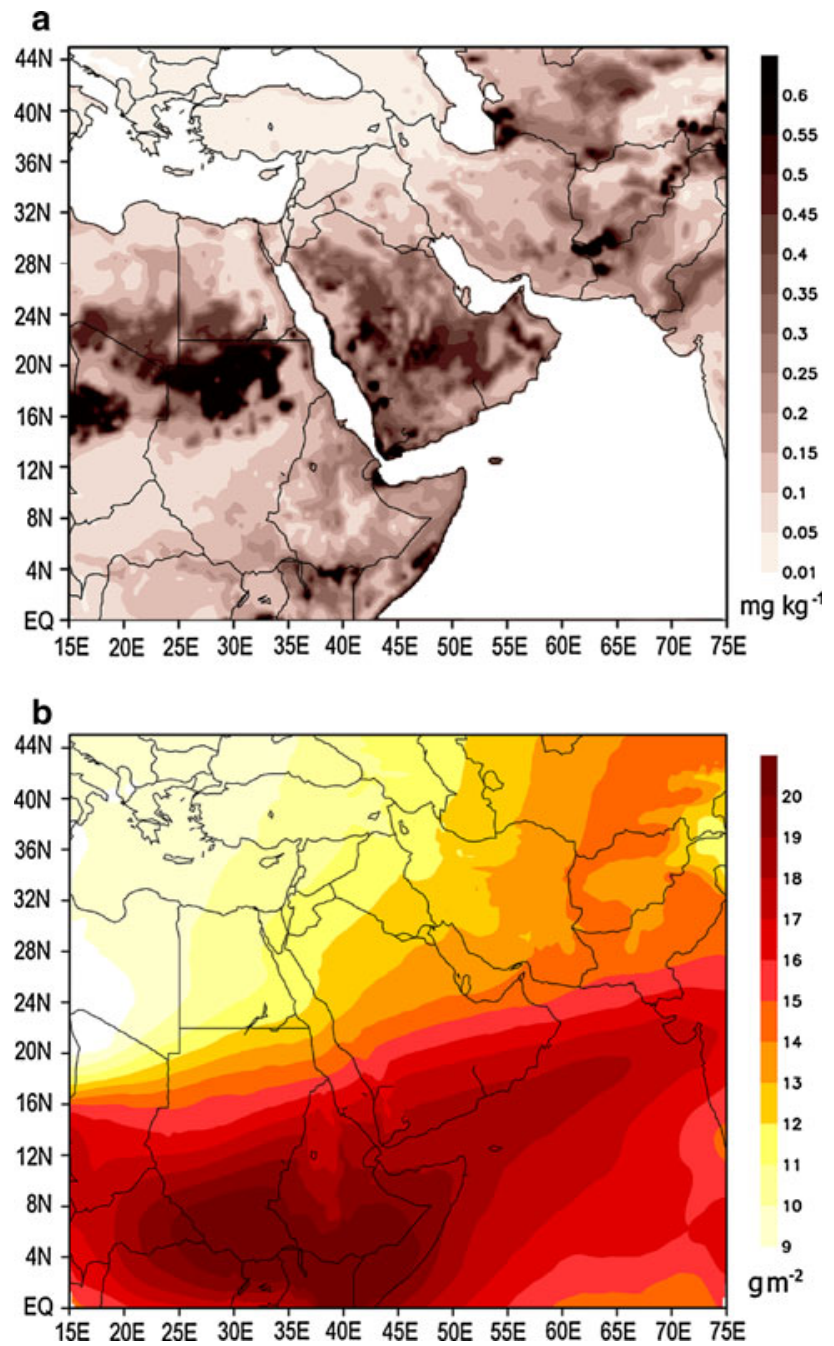

Fig. 2 The wet season a dust source (in $\mathrm{mg} \mathrm{kg}^{-1}$ ) and $\mathbf{b}$ aerosol optical depth (AOD) (in $\mathrm{g} \mathrm{m}^{-2}$ ), averaged over 1998-2009

in the southern side of the Peninsula (in regions close to the dust sources) with a net increase of more than $20 \mathrm{~W} \mathrm{~m}^{-2}$. These maxima are therefore related to the relatively higher surface albedo and dust concentration. It is worth noting that over the Red Sea and the Arabian Gulf, the TOA radiative forcing is negative, indicating an overall radiative cooling tendency of the surface-troposphere column, evidently related to the lower surface albedo existing over these bodies of water.

In opposition to the TOA, the clear-sky surface radiative forcing is negative over the entire Arabian Peninsula and the adjacent Indian Ocean, and mostly mirrors the aerosol optical depth. Therefore, the dust effect in the radiative balance is not felt only locally but is widely spread throughout the entire domain as a result of the extensive transport of dust plumes occurring in association with the regional circulation. This negative surface radiative forcing is also reported by Solmon et al. (2008) over Africa.

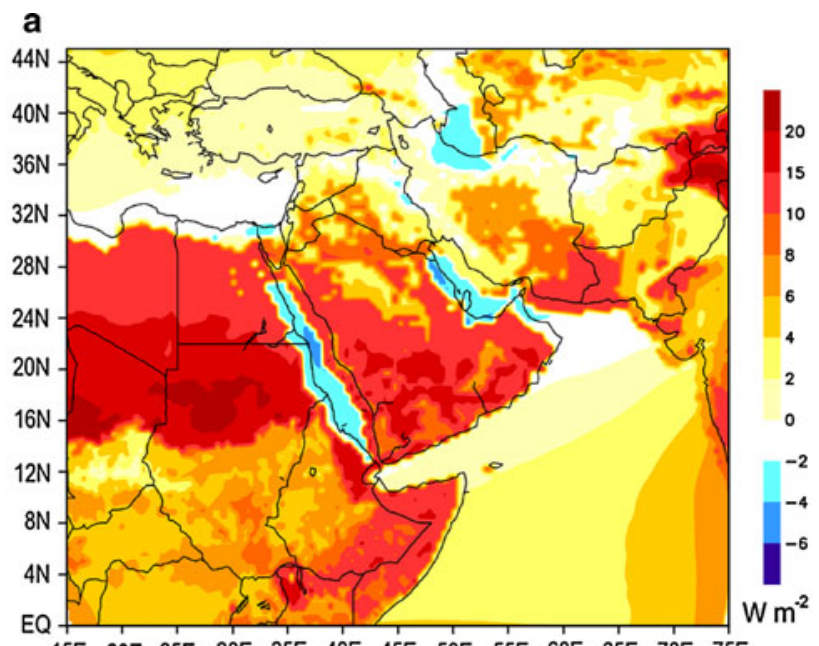

15E 20E 25E 30E 35E 40E 45E 50E 55E 60E 65E 70E 75E

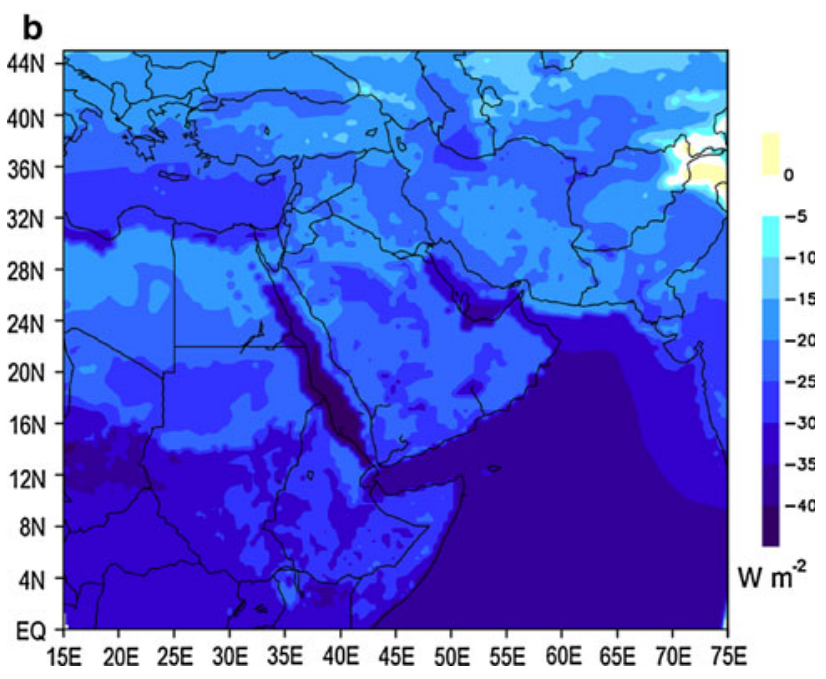

Fig. 3 The wet season clear sky a top of the atmosphere (TOA) and b surface total $(\mathrm{SW}+\mathrm{LW})$ radiative forcing (in $\mathrm{W} \mathrm{m}^{-2}$ ), averaged over 1998-2009

Such impact of dust on the radiation budget can also be illustrated by changes in the incident shortwave radiation received at ground level. Figure $4 \mathrm{a}-\mathrm{c}$ display the incoming shortwave radiation reaching the surface for the control simulation (Fig. 4a), the simulation with dust (Fig. 4b) and their difference (Fig. 4c). In both simulations (Fig. 4a, b), the maxima are located in the south-southwest of the Peninsula with a northward decreasing tendency of the seasonal values. The magnitudes in the control simulation are generally larger than those in the dust experiment. This is directly related to the dust absorption and scattering properties which tend to decrease the incoming shortwave radiation reaching the surface, as shown in Fig. 4c, with maxima over the southern regions of the Peninsula by up to $60 \mathrm{~W} \mathrm{~m}^{-2}$.

Similarly, the seasonal TOA outgoing longwave radiation from both simulations exhibits maxima over the 

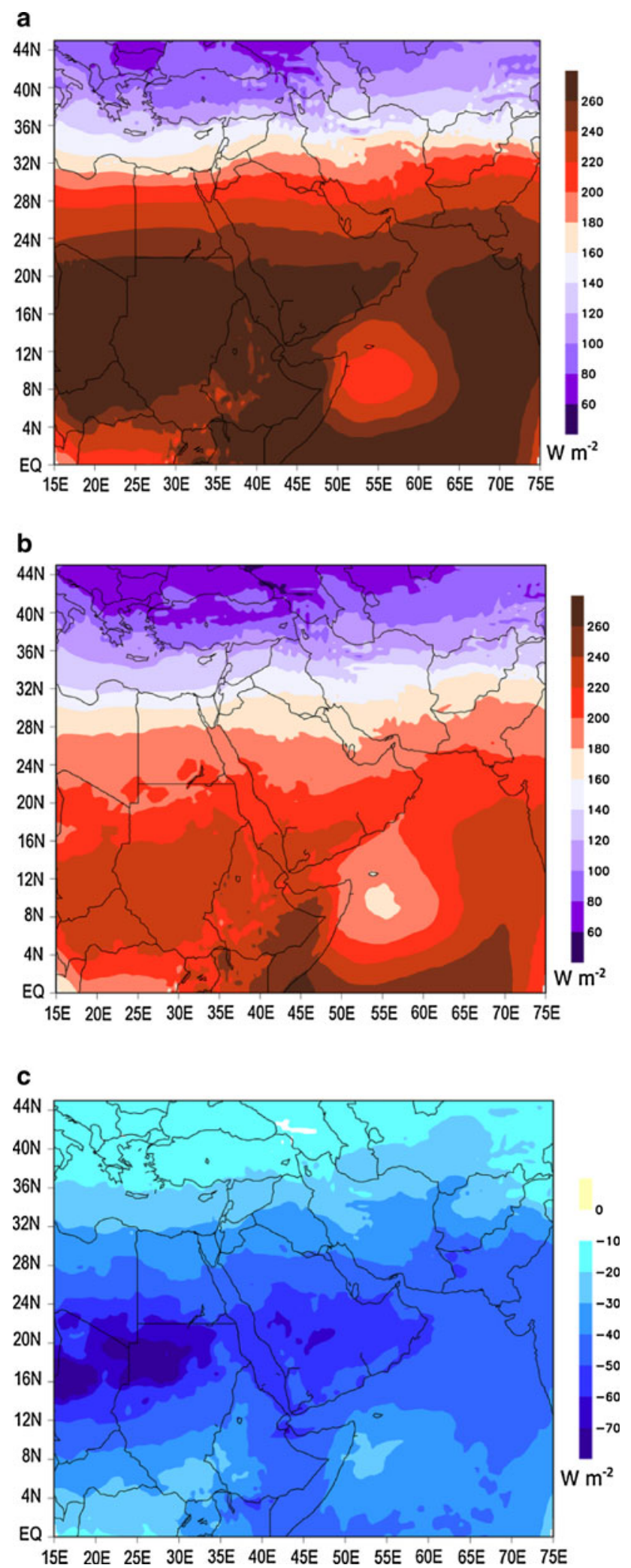

Fig. 4 The wet season incoming shortwave (SW) radiation (in $\mathrm{W} \mathrm{m}^{-2}$ ) for a RegCMcontrol, b RegCMdust and c RegCMdustRegCMcontrol, averaged over 1998-2009 southern Peninsula (Fig. 5a, b). However, the values are much larger in the control simulation for the entire domain (Fig. 5c). Therefore, the presence of dust plumes not only decreases the incoming shortwave but also the outgoing longwave radiation, although the clear-sky TOA forcing was positive. A reduction of outgoing longwave radiation was also reported by Yoshioka et al. (2007) for the African Sahel region, finding that, over the desert, longwave radiation interacts more efficiently with and is more absorbed by larger particles. Such changes modify the energy balance of the surface-atmosphere system, suggesting a reduced planetary albedo and indicating an overall warming tendency of the atmosphere column. This has strong implications for temperature distribution over the Peninsula.

Figure $6 \mathrm{a}-\mathrm{d}$ show the seasonal surface air temperature distribution from the CRU observation (Fig. 6a), the control simulation (Fig. 6b), the experiment with dust (Fig. 6c) and their difference (Fig. 6d), averaged over the period 1998-2009. As discussed in Almazroui (2012a), the regional model captures the basic spatial pattern of the seasonal surface air temperature, showing in general the lowest values in the northern and the highest values in the southern regions of the Peninsula. However, the simulation exhibits some warm biases, in the range of $3^{\circ} \mathrm{C}$. In the dust experiment, consistent with the negative surface radiative forcing, the temperature shows a decrease in the warm bias of more than $2^{\circ} \mathrm{C}$ over the entire Peninsula. The negative radiative forcing at the surface results in a reduction of surface temperature, consistent with the findings of Tummon et al. (2010). Thus, the inclusion of the dust significantly decreases the simulated temperature warm bias, with a larger decrease in the centre and the south of the Peninsula. This is confirmed by the regional average of mean bias and Root Mean Square Difference (RMSD) shown in Table 1 for the two homogenous sub-regions of the Peninsula. It reveals that the regional mean bias and the spatial RMSD are generally lower in the dust experiment than in the control simulation. This indicates a substantial improvement in the temperature simulation over the Peninsula, at least in our analysis, markedly so in the southern part of the Peninsula. Moreover, this also strengthens the low-level horizontal temperature gradient, and should strongly impact the regional circulation and therefore the water cycle.

\subsection{Impact on the water cycle and the regional circulation}

The water cycle has three main components on the seasonal timescale, which are rainfall, evaporation, and the difference between precipitation and evaporation (P-E). In this 

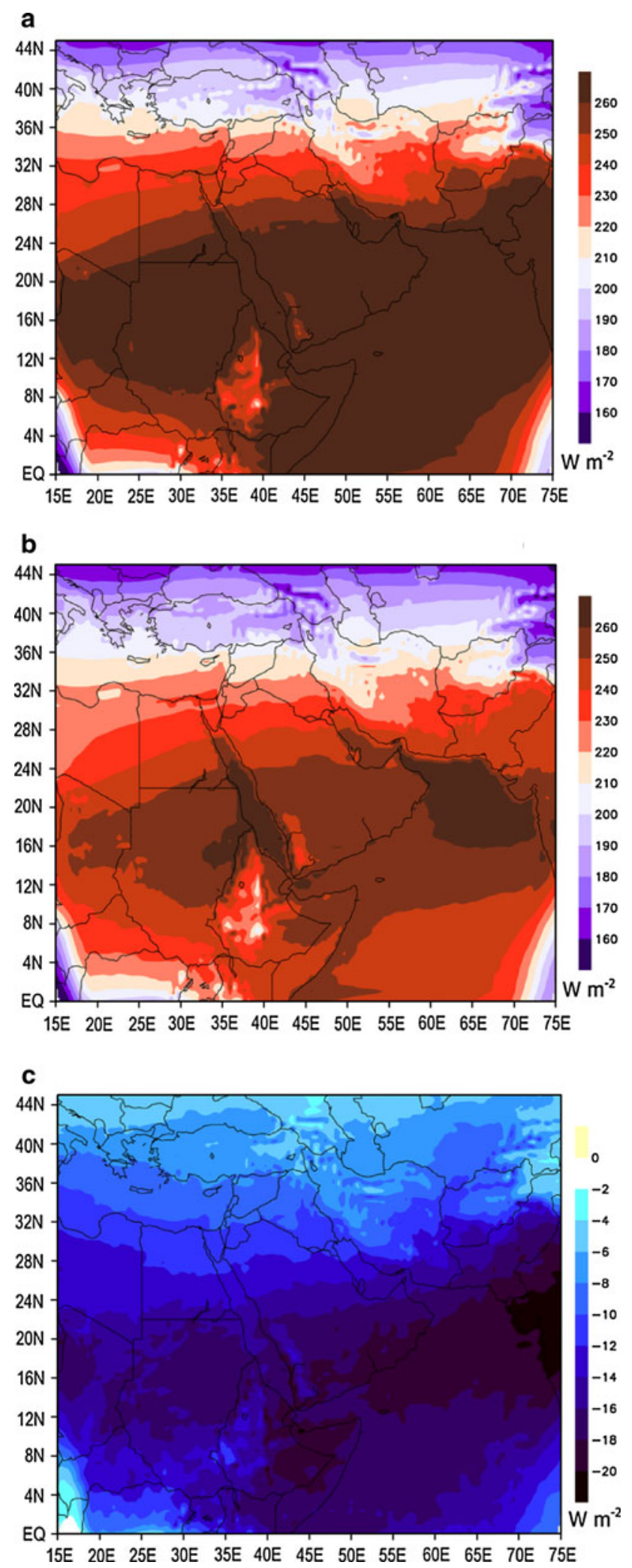

Fig. 5 The wet season outgoing longwave (LW) radiation (in $\mathrm{W} \mathrm{m}^{-2}$ ) for a RegCMcontrol, b RegCMdust and c RegCMdustRegCMcontrol, averaged over 1998-2009 section, the water cycle simulated by RegCM4 in control and dust experiments for the Arabian Peninsula is discussed.

The spatial pattern of the seasonal rainfall ( $\mathrm{mm} / \mathrm{month}$ ) is displayed in Fig. 7 for, respectively, the TRMM observation (Fig. 7a), the control simulation (Fig. 7b), the experiment with dust (Fig. 7c) and their difference (Fig. 7d). As shown in Fig. 7b, compared to TRMM, the regional model captures the basic spatial pattern of seasonal rainfall by locating the highest amount in the centre of the Peninsula and the lowest rates in the southeast. The result shows that RegCM4 tends to underestimate rainfall over the Peninsula and the ocean. In the dust experiment, the simulated amount of rainfall is in general higher in most of the Peninsula's regions and over the adjacent Arabian Sea, compared to the control run (Fig. 7c, d). Table 1 indicates that this larger rainfall amount simulated in the dust experiment is in line with improved performance on the part of the regional climate model. Therefore, the inclusion of dust in the regional climate model simulation decreases the dry bias found in the control simulation, leading to a more realistic rainfall distribution in the Peninsula.

Similar to the distribution of rainfall, the evaporation and the P-E for the different experiments and their differences are shown in Figs. 8a-c and 9a-c, respectively. As expected, the highest simulated rates of evaporation are over the Arabian Sea and the Red Sea and, to a lesser extent over the central and northern regions of the Peninsula, and the lowest over the south of the Peninsula in both simulations. Comparing the two experiments, the simulation with dust shows an increase in evaporation in those regions near the dust sources, which are the central and southern parts of the Peninsula, by up to $60 \%$. For the atmospheric P-E, the regional model simulates strong moisture divergence in the adjacent water bodies, and convergence over the entire Arabian Peninsula, with the largest occurring over the central regions. More importantly, the dust experiment dampens the decrease and amplifies the increase of P-E over the Arabian Sea and the Peninsula, respectively, by more than $60 \%$ compared to the control simulation values.

In general, the inclusion of dust in the simulation of the Arabian Peninsula's wet season climate leads to an increase of not only rainfall amounts but also evaporation and P-E, indicating thus an acceleration of the water cycle. The regional circulation that engenders such changes in the water cycle is now discussed next.

The low-level $(850 \mathrm{hPa})$ wind vectors for the wet season are displayed in Fig. 10 for the control simulation (Fig. 10a), the dust experiment (Fig. 10b) and their difference (Fig. 10c). Both simulations show the prevailing easterlies, laden with moisture from the Arabian Sea, entering 

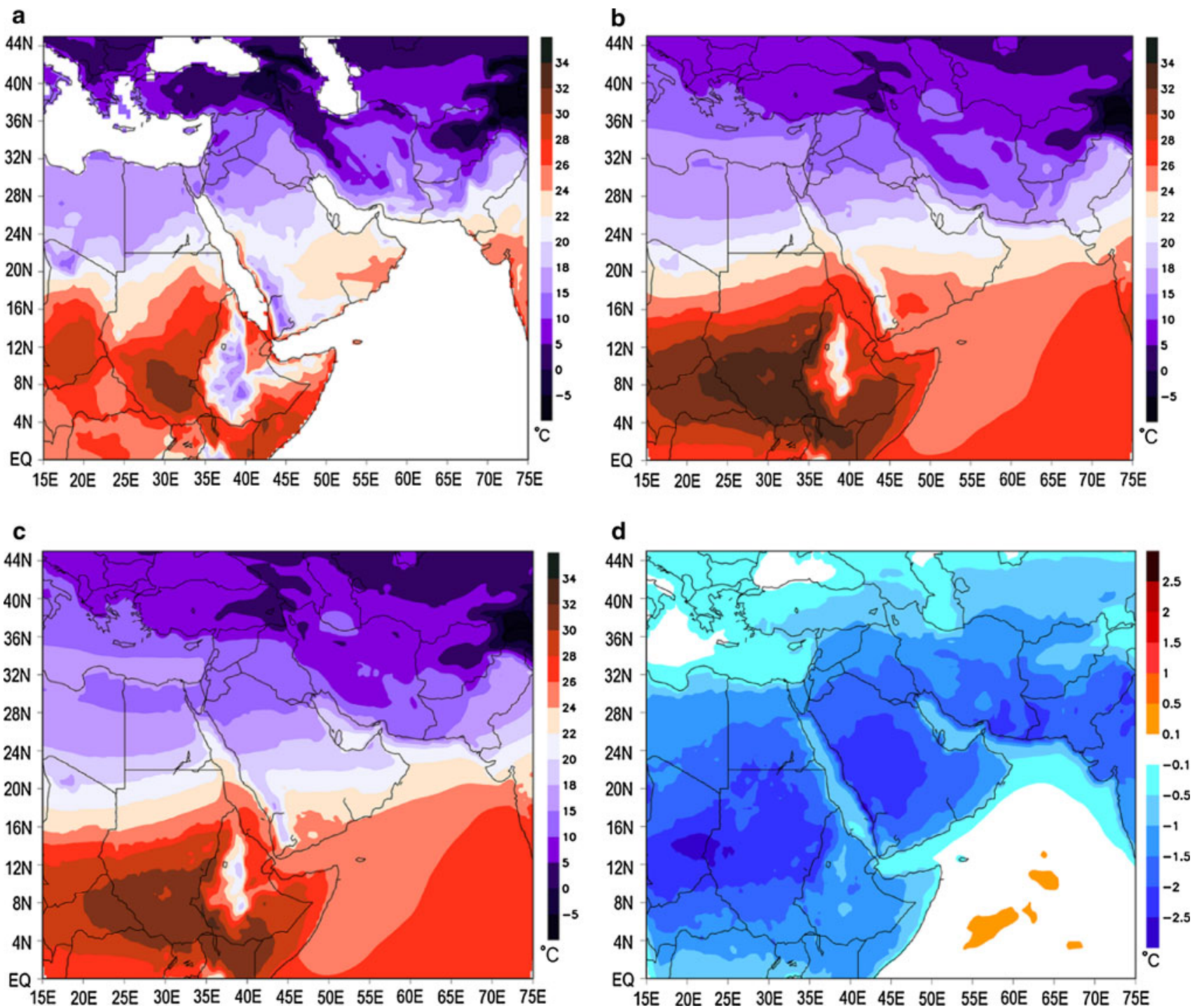

Fig. 6 The wet season air temperature $\left({ }^{\circ} \mathrm{C}\right)$ for a CRU, b RegCMcontrol, c RegCMdust and d RegCMdust-RegCMcontrol, averaged over 1998-2009

Table 1 Rainfall and temperature bias with root mean square difference (RMSD) for the two sub-regions NAP and SAP (see Fig. 1), averaged over 1998-2009

\begin{tabular}{|c|c|c|c|c|c|c|c|c|}
\hline & \multicolumn{4}{|l|}{ Bias } & \multicolumn{4}{|l|}{ RMSD } \\
\hline & \multicolumn{2}{|c|}{ Rainfall w.r.t. TRMM (\%) } & \multicolumn{2}{|c|}{ Temperature w.r.t. CRU $\left({ }^{\circ} \mathrm{C}\right)$} & \multicolumn{2}{|c|}{ Rainfall w.r.t. TRMM } & \multicolumn{2}{|c|}{ Temperature w.r.t. CRU } \\
\hline & Control & Dust & Control & Dust & Control & Dust & Control & Dust \\
\hline NAP & -55.60 & -51.70 & -0.10 & -2.14 & 1.07 & 1.01 & 1.67 & 4.56 \\
\hline SAP & -53.41 & -36.30 & 3.41 & 1.52 & 0.56 & 0.52 & 7.76 & 5.21 \\
\hline Average & -54.51 & -44.0 & 1.66 & -0.31 & 0.82 & 0.77 & 4.72 & 4.89 \\
\hline
\end{tabular}

the Peninsula. Their difference shows a return flow from the wetter Africa and the Red Sea into the Peninsula. In fact, the surface pressure anomaly (Fig. 11) displays a reduction over the Arabian Sea, a slight increase over the land area of the Arabian Peninsula and a much greater increase over Africa. These may be caused by an increased temperature gradient due to the reduction of lower surface air temperature simulated in the presence of dust in the Peninsula, 

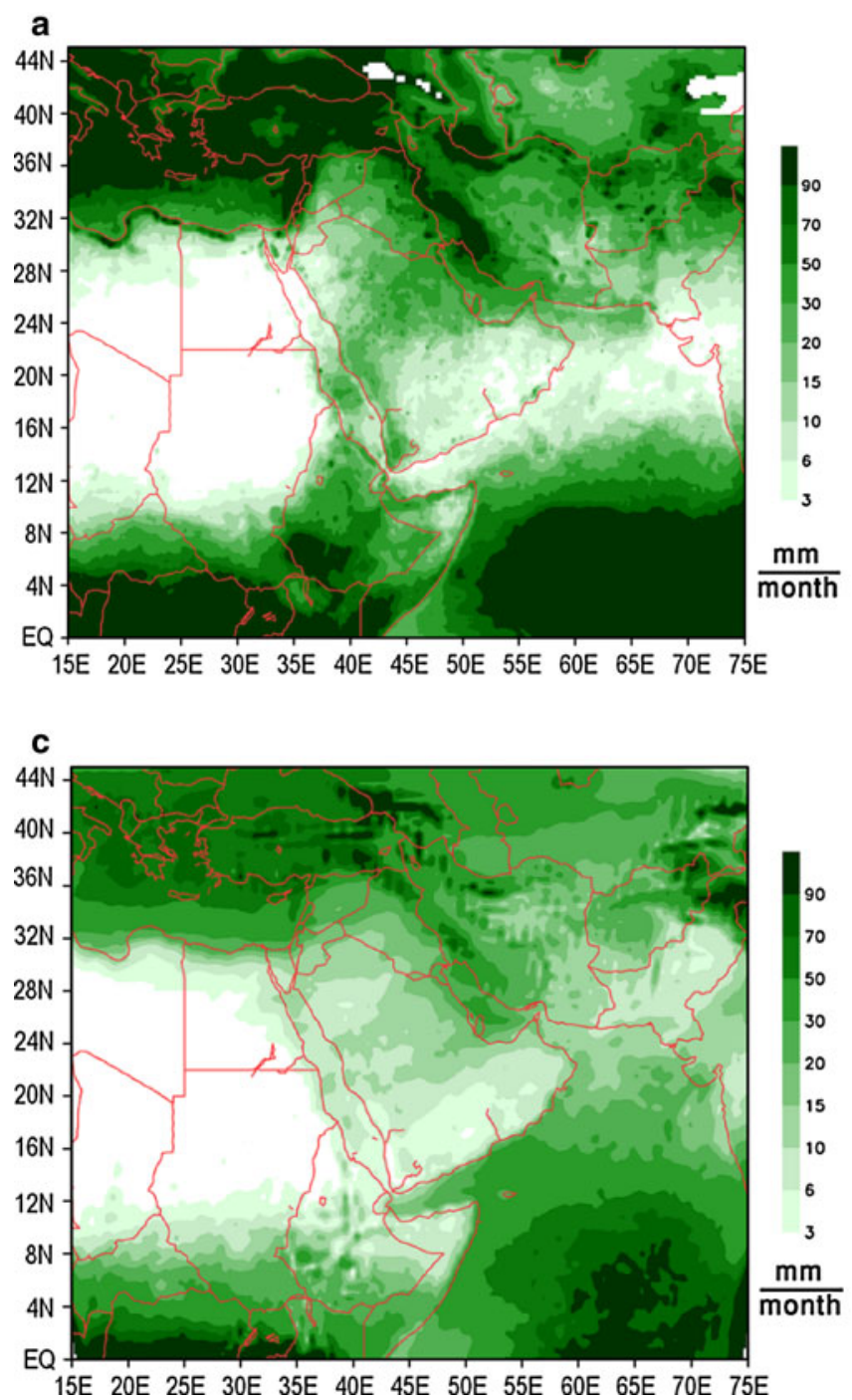

Fig. 7 The wet season rainfalls (mm/month) for a TRMM, b RegCMcontrol and c RegCMdust and d RegCMdust-RegCMcontrol, averaged over 1998-2009. Rainfall below $3 \mathrm{~mm} / \mathrm{month}$ is not

and may lead to more moisture convergence over the southern part of the Peninsula, consistent with the changes in the water budget discussed above. This conclusion can also be supported by the changes in the geopotential height vertical profile. The differences between the dust experiment and the control simulation in terms of geopotential height are shown in Fig. 12, which exhibits a decrease in the heights at almost all levels, with the greatest reduction around the mid-level (700-500 hPa). These lower heights in the middle and upper levels of the troposphere indicate a substantial reduction in the moisture divergence over the land, which would increase upward motion. Therefore, the presence of dust loading modifies the regional circulation and leads to less sinking of water vapor, which contributes to increased rainfall and intensification of the water cycle over the Arabian Peninsula.
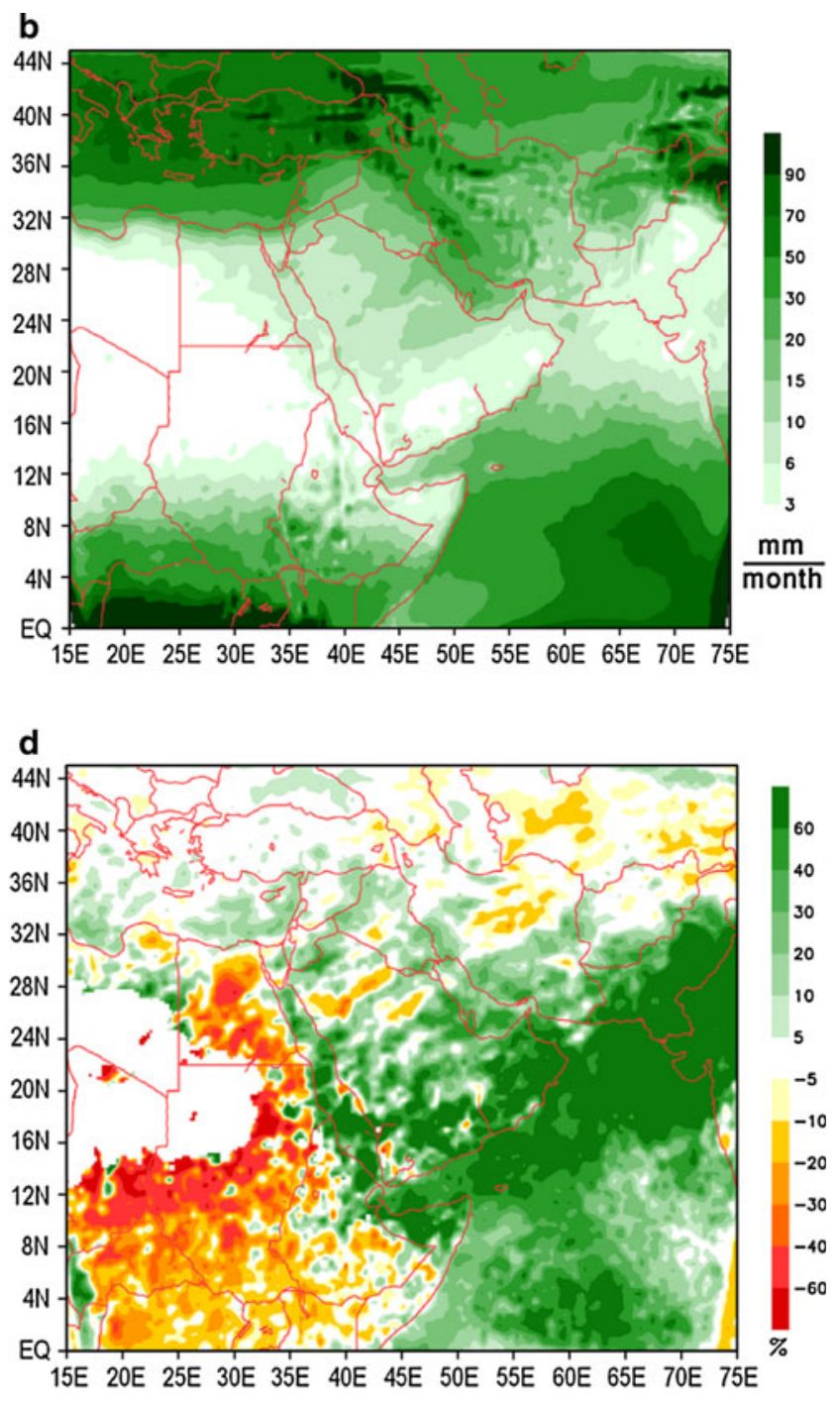

displayed in the figures. Rainfall lower than $1 \mathrm{~mm} / \mathrm{month}$ in RegCMcontrol is masked-out (in white) in $\mathbf{d}$

\section{Conclusions}

In this paper, we have analyzed 12-year continuous simulations (1998-2009) of the regional climate model ICTPRegCM4, using the Era-int driving forcing during the wet season (November through April) over the Arabian Peninsula. The model simulations with and without dust load have been presented in order to understand the impact of dust aerosol on the temperature and precipitation of the study region. Both the temperature and the precipitation of the control simulation are consistent with the CRU and TRMM observations in terms of the location of maxima and minima, respectively. The clear-sky total radiative forcing is positive at the TOA and negative at the surface over the Peninsula. The dust effect reduces incoming shortwave radiation by about $50-60 \mathrm{~W} \mathrm{~m}^{-2}$ at the surface, 

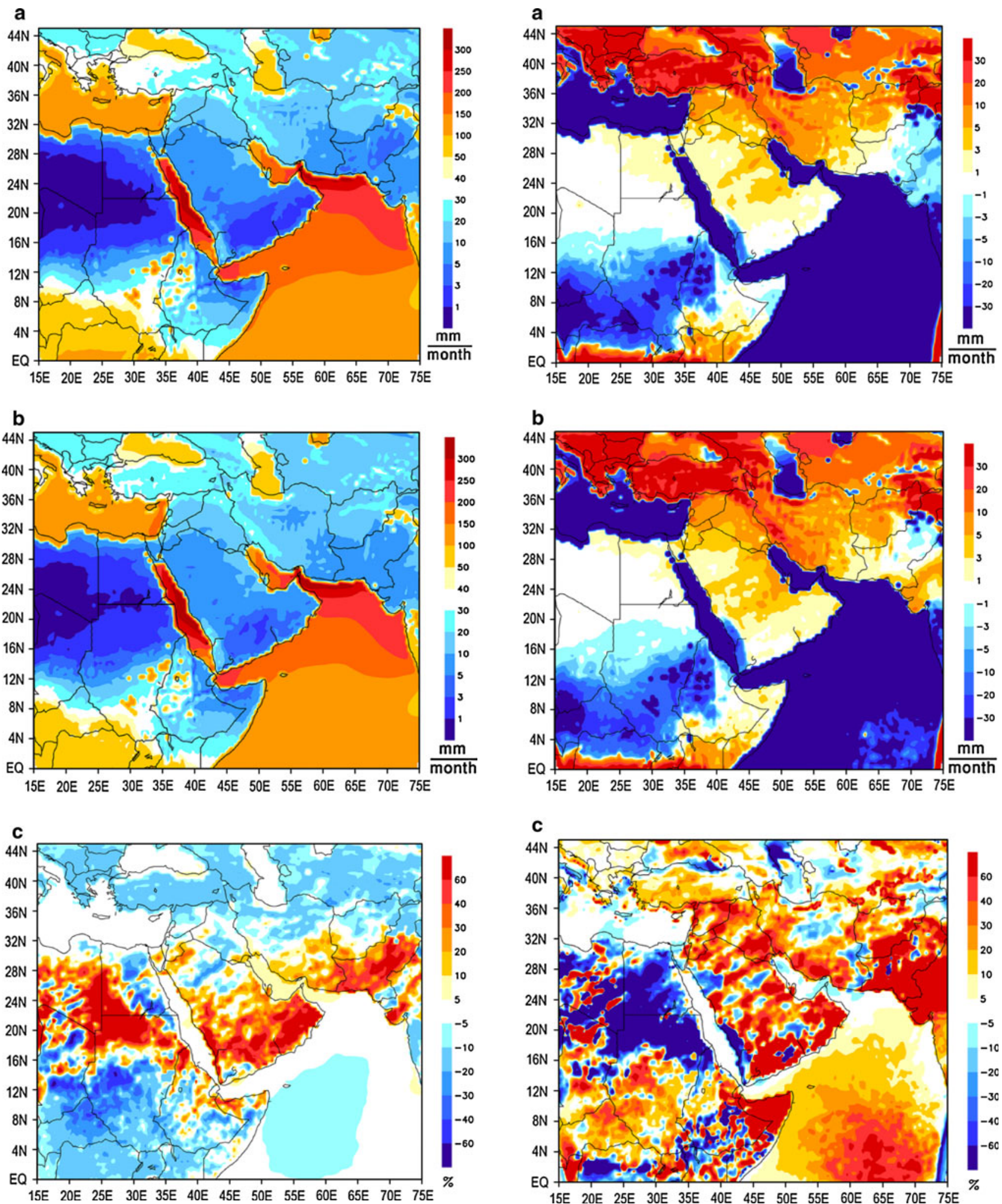

Fig. 8 The wet season evaporation ( $\mathrm{mm} / \mathrm{month}$ ) for a RegCMcontrol, b RegCMdust and c RegCMdust-RegCMcontrol, averaged over 1998-2009

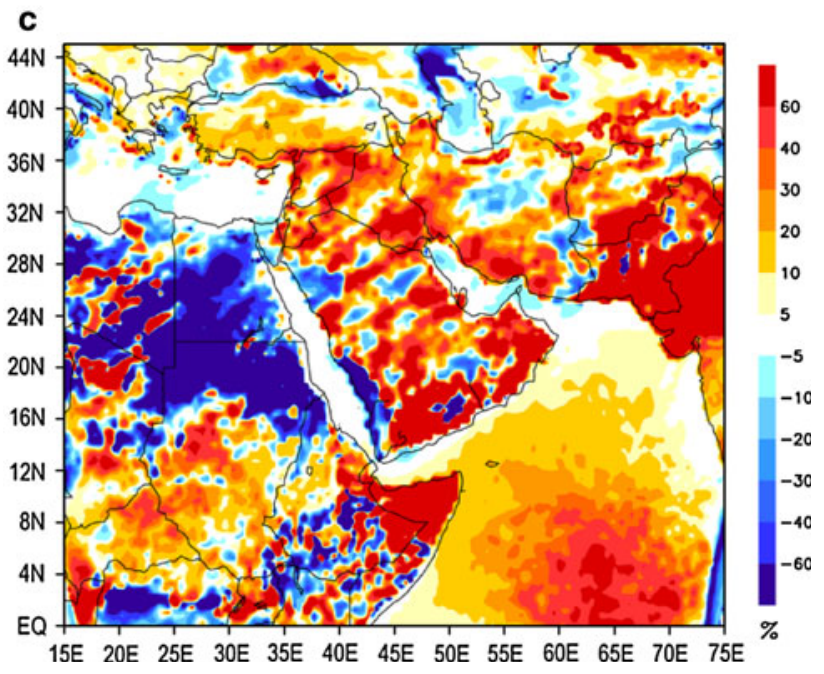

Fig. 9 The difference between precipitation and evaporation (P-E) (mm/month) for a RegCMcontrol, b RegCMdust and c RegCMdustRegCMcontrol, averaged over 1998-2009 during the wet season 


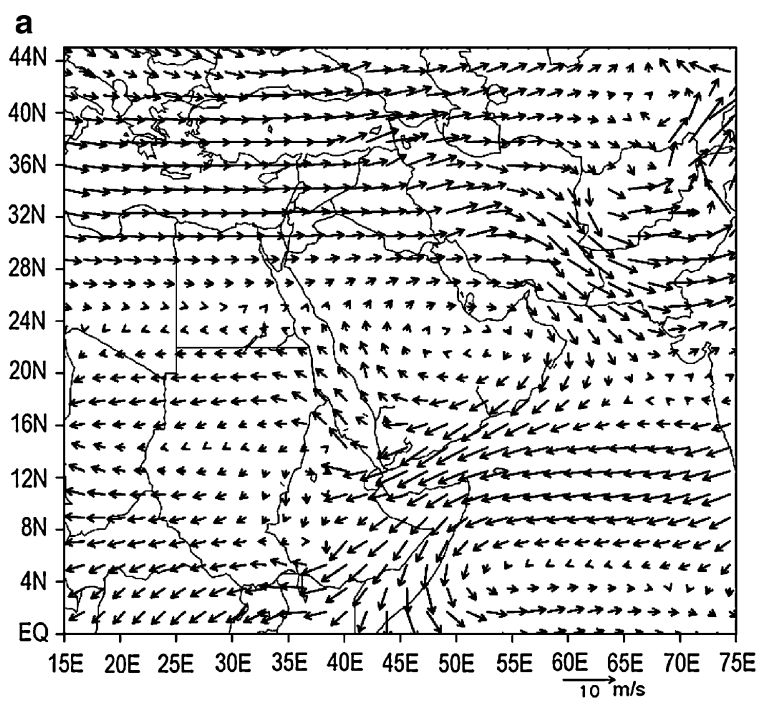

b

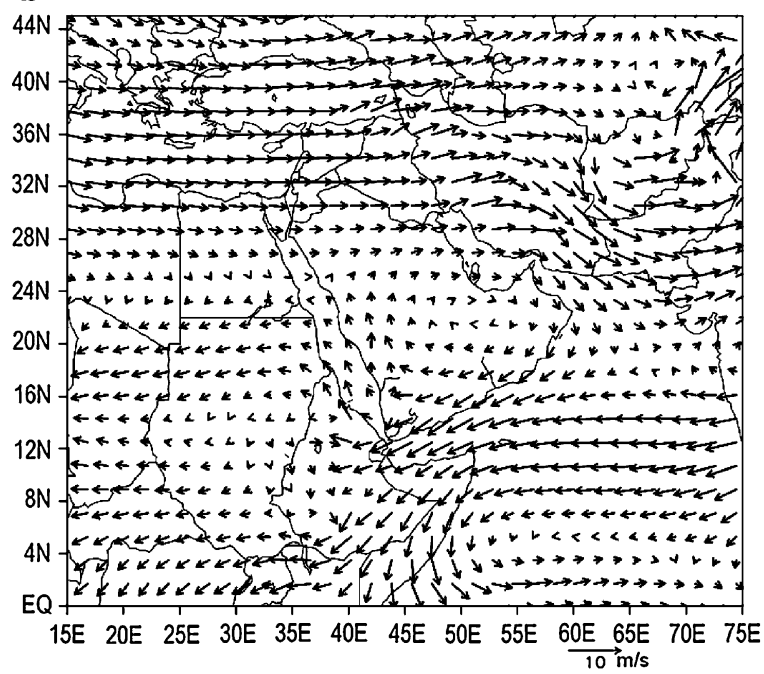

C

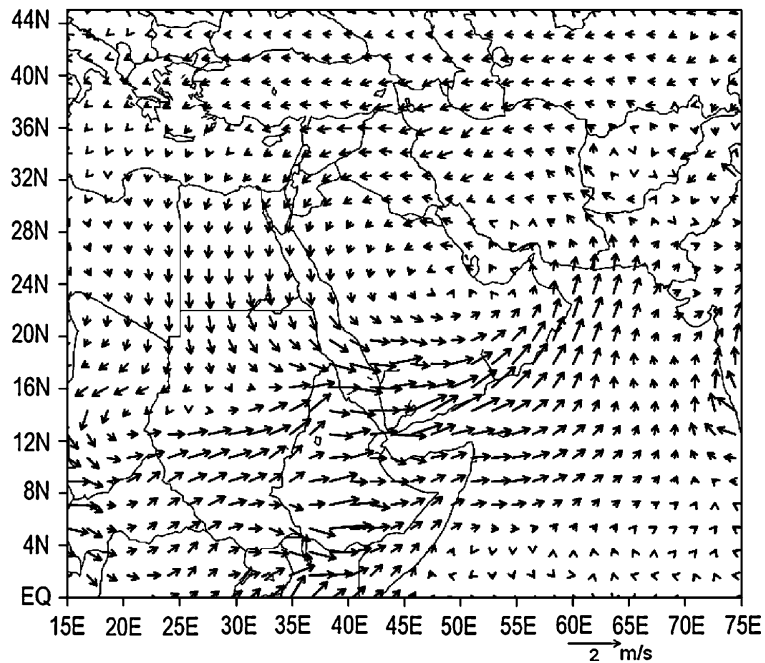

Fig. 10 The wet season wind field at $850 \mathrm{hPa}$ for a RegCMcontrol, b RegCMdust and c RegCMdust-RegCMcontrol, averaged over 1998-2009

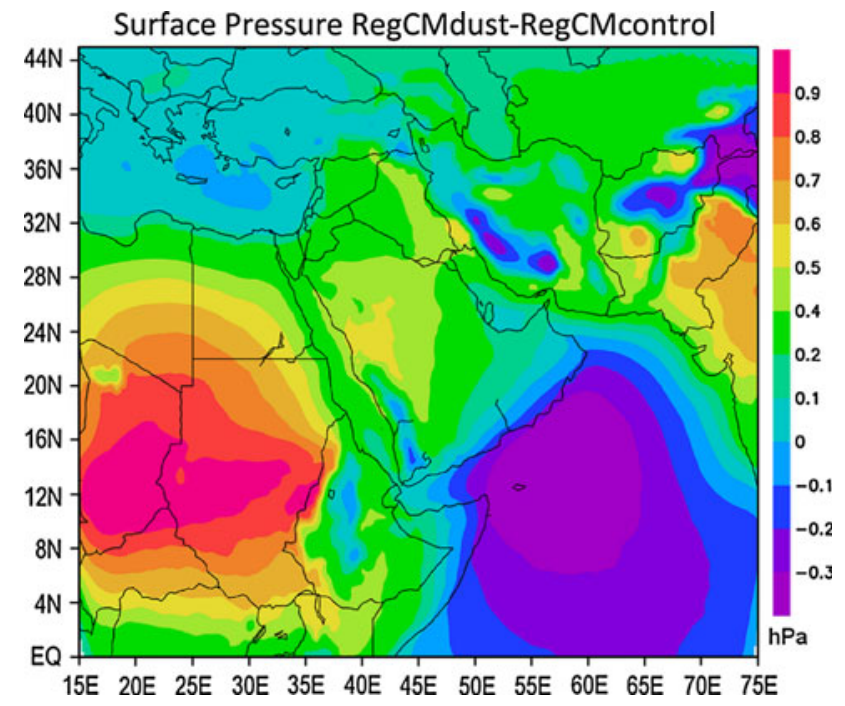

Fig. 11 The wet season surface pressure (hPa) anomaly (RegCMdust-RegCMcontrol), averaged over 1998-2009

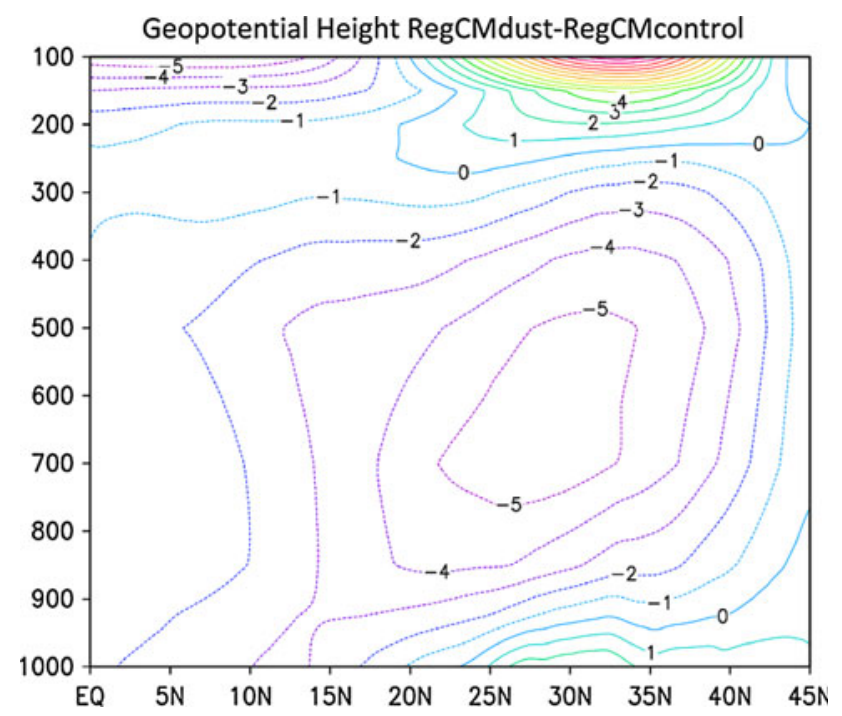

Fig. 12 Latitudinal variation of the wet season geopotential height (m) for RegCMdust-RegCMcontrol, averaged over 1998-2009 for longitude $40^{\circ}-55 \mathrm{E}^{\circ}$

where dust concentration is large. It also reduces the outgoing longwave radiation by about $12-16 \mathrm{~W} \mathrm{~m}^{-2}$ at the top of the atmosphere. The reduction of incoming and outgoing radiation results in a decrease in the surface air temperature and in an increase in the temperature gradient. The decrease in air temperature caused by the dust aerosol directly leads to a reduced temperature warm bias (reported in an earlier RegCM study over the Peninsula), and the increase in the temperature gradient modifies the atmospheric circulation. In fact, the return flow of wind from the wetter Africa and the decrease in the geopotential height simulated in the presence of dust lead to an increase in the 
atmospheric difference between precipitation and evaporation, rainfall and evaporation, an indication of an intensification of the hydrological cycle. The increase in the precipitation and the cutback of the surface air temperature by $\sim 2^{\circ} \mathrm{C}$ represent a significant success for RegCM4 over most parts of the Peninsula. Therefore, the inclusion of dust aerosol in ICTP-RegCM4 ultimately improves the simulation of wet season climate in the Arabian Peninsula.

Acknowledgments The authors would like to acknowledge the RegCM4 group of the Abdus Salam International Centre for Theoretical Physics (ICTP), Trieste, Italy for providing the model with boundary forcings. The TRMM and CRU data were acquired from their respective websites.

Open Access This article is distributed under the terms of the Creative Commons Attribution License which permits any use, distribution, and reproduction in any medium, provided the original author(s) and the source are credited.

\section{References}

Abdullah MA, Al-Mazroui M (1998) Climatological study of the southwestern region of Saudi Arabia. I. Rainfall analysis. Clim Res 9:213-223

Al-Jerash MA (1985) Climatic subdivisions in Saudi Arabia: an application of principal component analysis. Int $\mathrm{J}$ Climatol 5:307-323

Almazroui M (2011a) Sensitivity of a regional climate model on the simulation of high intensity rainfall events over the Arabian Peninsula and around Jeddah (Saudi Arabia). Theor Appl Climatol 104:261-276. doi:10.1007/s00704-010-0387-3

Almazroui M (2011b) Calibration of TRMM rainfall climatology over Saudi Arabia during 1998-2009. Atmos Res 99:400-414

Almazroui M (2012a) Dynamical downscaling of rainfall and temperature over the Arabian Peninsula using RegCM4. Clim Res. doi:10.3354/cr01073

Almazroui M (2012b) The life cycle of extreme rainfall events over western Saudi Arabia simulated by a regional climate model: Case study of November 1996. Atmósfera 25:23-41

Al-Mazroui M (1998) Climatological study over the southwestern region of the Kingdom of Saudi Arabia with special reference to rainfall distribution. Master's thesis, Department of Meteorology, Faculty of Meteorology, Environment and Arid Land Agriculture, King Abdulaziz University, Jeddah

Ångström A (1962) Atmospheric turbidity, global illumination and planetary albedo of the Earth. Tellus 14:435-450

Atlas (1984) Water Atlas of Saudi Arabia. Water resource department, Ministry of Agriculture and Water. Riyadh, pp 2-19

Bergant K, Belda M, Halenka T (2007) Systematic errors in the simulation of European climate (1961-2000) with RegCM3 driven by NCEP/NCAR reanalysis. Int J Climatol 27:455-472

Bishop MA (2010) Nearest neighbor analysis of mega-barchanoid dunes, Ar Rub' al Khali, sand sea: the application of geographical indices to the understanding of dune field selforganization, maturity and environmental change. Geomorphol 120:186-194

Chakraborty A, Behera SK, Mujumdar M, Ohba R, Yamagata T (2006) Diagnosis of tropospheric moisture over Saudi Arabia and influences of IOD and ENSO. Mon Weather Rev 134:598-617
Cuadra SV, da Rocha RP (2007) Sensitivity of regional climatic simulation over Southeastern South America to SST specification during Austral summer. Int J Climatol 27:793-804

Dai A, Giorgi F, Trenberth K (1999) Observed and model simulated diurnal cycles of precipitation over the contiguous United States. J Geophys Res 104:6377-6402

Dash SK, Shekhar MS, Singh GP (2006) Simulation of Indian summer monsoon circulation and rainfall using RegCM3. Theor Appl Climatol 86(1-4):161-172

Dickinson RE, Henderson-Sellers A, Kennedy PJ (1993) Biosphereatmosphere transfer scheme (BATS) version le as coupled to the NCAR community climate model. NCAR Tech. Note NCAR/ TN-387+STR, 72

Edgell HS (2006) Arabian deserts: nature. Origin and Evolution, Springer

Fritsch JM, Chappell CF (1980) Numerical prediction of convectively driven mesoscale pressure systems: part 1 . Convective parameterization. J Atmos Sci 37:1722-1733

Gao X, Pal JS, Giorgi F (2006) Projected changes in mean and extreme precipitation over the Mediterranean region from a high resolution double nested RCM simulation. Geophys Res Lett 33:L03706. doi:10.1029/2005GL024954

Giorgi F, Marinucci MR, Bates G, DeCanio G (1993) Development of a second generation regional climate model (RegCM2), part II: Convective processes and assimilation of lateral boundary conditions. Mon Weather Rev 121:2814-2832

Giorgi F, Coppola E, Solmon F, Mariotti L, Sylla M, Bi X, Elguindi N, Diro GT, Nair V, Giuliani G, Cozzini S, Guettler I, O'Brien T, Tawfik A, Shalaby A, Zakey AS, Steiner A, Stordal F, Sloan L, Brankovic C (2012) RegCM4: model description and preliminary tests over multiple CORDEX domains. Clim Res. doi: $10.3354 / \mathrm{cr} 01018$

Grell GA (1993) Prognostic evaluation of assumptions used by cumulus parameterizations. Mon Weather Rev 121:764-787

Holtslag AAM, de Bruijn EIF, Pan HL (1990) A high resolution air mass transformation model for short-range weather forecasting. Mon Weather Rev 118:1561-1575

Kiehl JT, Hack JJ, Bonan GB, Boville BA, Breigleb BP, Williamson DL, Rasch PJ (1996) Description of the NCAR community climate model (CCM3), NCAR Tech. Note NCAR/TN-4201STR, 152

Konaré A, Zakey AS, Solmon F, Giorgi F, Rauscher S, Ibrah S, Bi X (2008) A regional climate modeling study of the effect of desert dust on the West African monsoon. J Geophys Res 113:D12206. doi:10.1029/2007JD009322

Krichak SO, Alpert P, Kunin P (2010) Numerical simulation of seasonal distribution of precipitation over the eastern Mediterranean with a RCM. Clim Dyn 34(1):47-59

Kummerow C, Simpson J, Thiele O, Barnes W, Chang ATC, Stocker E, Adler RF, Hou A, Kakar R, Wentz F, Ashcroft P, Kozu T, Hong Y, Okamoto K, Iguchi T, Kuroiwa H, Im E, Haddad Z, Huffman G, Ferrier B, Olson WS, Zipser E, Smith EA, Wilheit TT, North G, Krishnamurti T, Nakamura K (2000) The Status of the Tropical Rainfall Measuring Mission (TRMM) after two years in orbit. J Appl Meteorol 39:1965-1982

Loveland TR, Reed BC, Brown JF, Ohlen DO, Zhu Z, Yang L, Merchant JW (2000) Development of a global land cover characteristics database and IGBP DISCover from $1 \mathrm{~km}$ AVHRR data. Int J Remote Sens 21:1303-1330

McCormic RA, Ludwig JH (1967) Climate modifications by atmospheric aerosols. Science 156:1358-1359

Mitchell TD, Jones PD (2005) An improved method of constructing a database of monthly climate observations and associated high-resolution grids. Int J Climatol 25:693-712. doi:10.1002/ joc. 1181 
Pal JS, Small E, Eltahir E (2000) Simulation of regional-scale water and energy budgets: representation of subgrid cloud and precipitation processes within RegCM. J Geophys Res 105:29579-29594. doi:10.1029/2000JD900415

Pal JS, Giorgi F, Bi X, Elguindi N, Solmon F, Rauscher SA, Francisco R, Zakey A, Winter J, Ashfaq M, Syed F, Bell JL, Diffenbaugh NS, Karmacharya J, Konaré A, Martinez D, Da Rocha RP, Sloan LC, Steiner AL (2007) Regional climate modeling for the developing world: the ICTP RegCM3 and RegCNET. Bull Amer Meteor Soc 88:1395-1409

Park EH, Hong SY, Kang HS (2008) Characteristics of an East-Asian summer monsoon climatology simulated by the RegCM3. Meteor Atmos Phys 100:139-158

Ragab R, Prudhomme C (2000) Climate change and water resources management in the southern Mediterranean and Middle East countries. The Second World Water Forum, 17-22, March 2000, The Hague

Reynolds RW, Rayner NA, Smith TM, Stokes DC, Wang W (2002) An improved in situ and satellite SST analysis for climate. J Clim 15:1609-1625

Simmons A, Uppala S, Dee D, Kobayashi S (2007) ERA-Interim: new ECMWF reanalysis products from 1989 onwards. ECMWF Newsl 110:25-35

Solmon F, Giorgi F, Liousse C (2006) Aerosol modeling for regional climate studies: application to anthropogenic particles and evaluation over a European/African domain. Tellus 58B:51-72

Solmon F, Mallet M, Elguindi N, Giorgi F, Zakey A, Konaré A (2008) Dust aerosol impact on regional precipitation over western Africa: mechanisms and sensitivity to absorption properties. Geophys Res Lett 35:L24705. doi:10.1029/2008 GL035900

Stier P, Feichter J, Kinne S, Kloster S, Vignati E, Wilson J, Ganzeveld L, Tegen I, Werner M, Balkanski Y, Schulz M, Boucher O, Minikin A, Petzold A (2005) The aerosol-climate model ECHAM5-HAM. Atmos Chem Phys 5:1125-1156

Sylla MB, Dell'Aquila A, Ruti PM, Giorgi F (2010) Simulation of the intraseasonal and the interannual variability of rainfall over West Africa with RegCM3 during the monsoon period. Int J Climatol 30:1865-1883. doi:10.1002/joc.2029

Tegen I, Harrison SP, Kohfeld K, Prentice IC, Coe M, Heimann M (2002) Impact of vegetation and preferential source areas on global dust aerosol: results from a model study. J Geophys Res 107:4576-4597

Tummon F, Solmon F, Liousse C, Tadross M (2010) Simulation of the direct and semi-direct aerosol effects on the southern Africa regional climate during the biomass burning season. J Geophys Res 115:D19206. doi:10.1029/2009JD013738

Wu J, Fu C, Han Z, Tang J, Xu Y, Zhang R (2010) Simulation of the direct effects of dust aerosol on climate in East Asia. Particuology 8:301-307

Yoshioka M, Mahowald NM, Conley AJ, Collins WD, Fillmore DW, Zender CS, Coleman DB (2007) Impact of desert dust radiative forcing on Sahel precipitation: relative importance of dust compared to sea surface temperature variations, vegetation changes, and greenhouse gas warming. J Clim 20:1445-1467

Zakey AS, Solmon F, Giorgi F (2006) Development and testing of a desert dust module in a regional climate model. Atmos Chem Phys 6:1749-1792 